\title{
Effect of carbon starvation on toluene degradation activity by toluene monooxygenase-expressing bacteria
}

\author{
David R. Johnson ${ }^{1}$, Joonhong Park ${ }^{2, *}$, Jerome J. Kukor ${ }^{3,4}$ \& Linda M. Abriola ${ }^{1,5}$ \\ ${ }^{1}$ Department of Civil and Environmental Engineering, University of Michigan, Ann Arbor, MI 48109-2125, \\ USA; ${ }^{2}$ School of Civil and Environmental Engineering, Yonsei University, Shinchon-dong 134, Seodaemoon-gu, \\ 120-749, Seoul, Republic of Korea; ${ }^{3}$ Biotechnology Center for Agriculture and the Environment, Rutgers \\ University, New Brunswick, NJ 08901-8520, USA; ${ }^{4}$ Department of Environmental Sciences, Cooks College, \\ Rutgers University, New Brunswick, NJ 08901-8520, USA; ${ }^{5}$ Department of Civil and Environmental \\ Engineering, Tufts University, Medford, MA 02155, USA (*author for correspondence: e-mail: parkj@) \\ yonsei.ac.kr)
}

Accepted 8 August 2005

Key words: aromatic oxygenase, carbon starvation, TCE co-metabolism, toluene oxidizing bacteria

\begin{abstract}
Subsurface bacteria commonly exist in a starvation state with only periodic exposure to utilizable sources of carbon and energy. In this study, the effect of carbon starvation on aerobic toluene degradation was quantitatively evaluated with a selection of bacteria representing all the known toluene oxygenase enzyme pathways. For all the investigated strains, the rate of toluene biodegradation decreased exponentially with starvation time. First-order deactivation rate constants for TMO-expressing bacteria were approximately an order of magnitude greater than those for other oxygenase-expressing bacteria. When growth conditions (the type of growth substrate and the type and concentration of toluene oxygenase inducer) were varied in the cultures prior to the deactivation experiments, the rate of deactivation was not significantly affected, suggesting that the rate of deactivation is independent of previous substrate/inducer conditions. Because TMO-expressing bacteria are known to efficiently detoxify TCE in subsurface environments, these findings have significant implications for in situ TCE bioremediation, specifically for environments experiencing variable growth-substrate exposure conditions.
\end{abstract}

Abbreviations: AMO - ammonia monooxygenase; BM - basal salt medium; CFU - colony forming unit; MMO - methane monooxygenase; TCE - trichloroethylene; TDO - toluene dioxygenase; TMO - toluene monooxygenase; T4MO - toluene-4-monooxygenase; TNA - tryptone nutrient agar

\section{Introduction}

Trichloroethylene (TCE), a widespread contaminant of soil and groundwater, can be co-oxidized in aerobic environments by a variety of aromatic and aliphatic bacterial oxygenases (Arciero et al. 1989; Ensign et al. 1992; Folsom et al. 1990; Fox et al. 1990; Heald \& Jenkins 1994; Lontoh \& Semrau 1998; Malachowsky et al. 1994; Zylstra et al. 1989). Utilization of oxygenase-expressing bacteria for in situ biodegradation of TCE, therefore, is receiving attention as a potential and promising remediation strategy. Toluene monooxygenase (TMO)-expressing bacteria are of specific interest because they are relatively tolerant to TCE-mediated toxicity (Mars et al. 1996; Park et al. 2002). Furthermore, at a site undergoing toluene addition to stimulate TCE co-oxidation, 
TMO-expressing bacteria were identified as a major aromatic-degrading population (Hopkins \& McCarty 1995; McCarty et al. 1998).

Environmental stress conditions can significantly affect cellular physiology, such as rates of biodegradation. For subsurface bacteria, understanding the effects of carbon starvation on rates of biodegradation is of particular interest because the subsurface environment is commonly carbonlimited (Ghiorse \& Wilson 1988; Morita 1993). Several investigations with oxygenase-expressing bacteria have explored the effects of carbon starvation on biodegradation activity. These investigations include experiments with bacteria that express ammonia monooxygenase (AMO) (Jones \& Morita 1985), methane monooxygenase (MMO) (Alvarez-Cohen \& McCarty 1991; Henry \& Grbac-Galic 1991; Roslev \& King 1994), toluene dioxygenase (TDO) (Costura \& Alvarez 2000; Jenkins \& Heald 1996), and toluene-4monooxygenase (T4MO) (Park et al. 2001). Experiments revealed that the rate of primary substrate biodegradation is reduced exponentially with increasing carbon starvation time. Interestingly, when first-order decay models were applied to experimental data, the first-order rate constant (deactivation rate) for the T4MO-expresing R. pickettii $\mathrm{PKO} 1$ bacterium $\left(4.68 \mathrm{~d}^{-1}\right)$ was more than an order of magnitude greater than deactivation rates observed for the other oxygenaseexpressing bacteria $\left(<0.2-0.36 \mathrm{~d}^{-1}\right)$ (Costura \& Alvarez 2000; Jenkins \& Heald 1996; Jones \& Morita 1985; Park 2001; Roslev \& King 1994). Such a wide range of deactivation rates suggests that deactivation may have a significant influence on the effectiveness of bioremediation processes and the accuracy of in situ biodegradation rate predictions (Lang et al. 1997; Park et al. 2001). However, the dependence of deactivation rates on biological and environmental factors is currently unclear, complicating the ability to incorporate deactivation information in prediction and design methodologies.

The primary objective of this work was to examine whether rapid deactivation of biodegradation activity in response to carbon starvation is a general characteristic of TMO-expressing bacteria. To explore this question, the effect of carbon starvation on toluene degradation activity was quantified for a selection of bacteria representing all the known toluene oxygenase enzyme pathways. The bacterial strains investigated in this study and their corresponding toluene oxygenase pathways are Burkholderia cepacia G4 (Figure 1, pathway A), Ralstonia pickettii PKO1 (Figure 1, pathway B), Pseudomonas mendocina KR1 (Figure 1, pathway C), Pseudomonas putida mt-2 (Figure 1, pathway D), and Pseudomonas putida F1 (Figure 1, pathway E). With the exception of the toluene methyl monooxygenase pathway (Figure 1, pathway D), all the toluene biotransformation pathways can co-oxidize TCE (Malachowsky et al. 1994; Leahy et al. 1996; Shields et al. 1989; Zylstra et al. 1989). Because subsurface bacteria are commonly exposed to highly variable growth/induction conditions (McCarty et al. 1998; Vroblesky \& Chapelle 1994), the dependence of deactivation rates on prior substrate/inducer exposure conditions was also investigated.

\section{Materials and methods}

\section{Bacterial strains and growth conditions}

The following bacterial strains were grown in pure culture: B. cepacia G4, B. cepacia G4-PR $1_{31}$, $P$. mendocina $\mathrm{KR} 1$, P putida $\mathrm{F} 1, P$. putida $\mathrm{mt}-2$, and $R$. pickettii PKO1 (see Table 1 for relevant strain characteristics). Cells previously stored at $-70{ }^{\circ} \mathrm{C}$ were serially diluted and plated on tryptone nutrient agar (TNA) solid media (Olsen \& Hansen 1976). After incubation for 3 days at $30{ }^{\circ} \mathrm{C}, 10$ colonies were transferred to a $2-1$ culture flask and resuspended in $200 \mathrm{ml}$ of pre-oxygenated basal salts medium (BM) (Leahy et al. 1996). Uninduced cells were grown by amending culture flasks with $1000 \mathrm{mg}$ sodium DL-lactate $1^{-1}$ followed by incubation for $18 \mathrm{~h}$ at $30^{\circ} \mathrm{C}$. A 1:10 liquid to headspace ratio and shaking maintained aerobic conditions during cellular growth. Our preliminary examination with a similar experimental set-up ensured aerobic conditions (aqueous $\mathrm{O}_{2}$ concentrations $>2.5 \mathrm{mg} \mathrm{l}^{-1}$ ) throughout the growth cycle. After incubation, the $\mathrm{A}_{425}$ (optical density at $425 \mathrm{~nm}$ ) of late-exponential-phase cell cultures was typically between 0.8 and 1.0 .

Toluene-induced cells were grown by amending culture flasks with toluene as the only growth substrate or with toluene plus $1000 \mathrm{mg}$ sodium DLlactate $1^{-1}$ and incubating for $18-72 \mathrm{~h}$ at $30^{\circ} \mathrm{C}$. Toluene was supplied by suspending a $1.8-\mathrm{ml}$ glass 


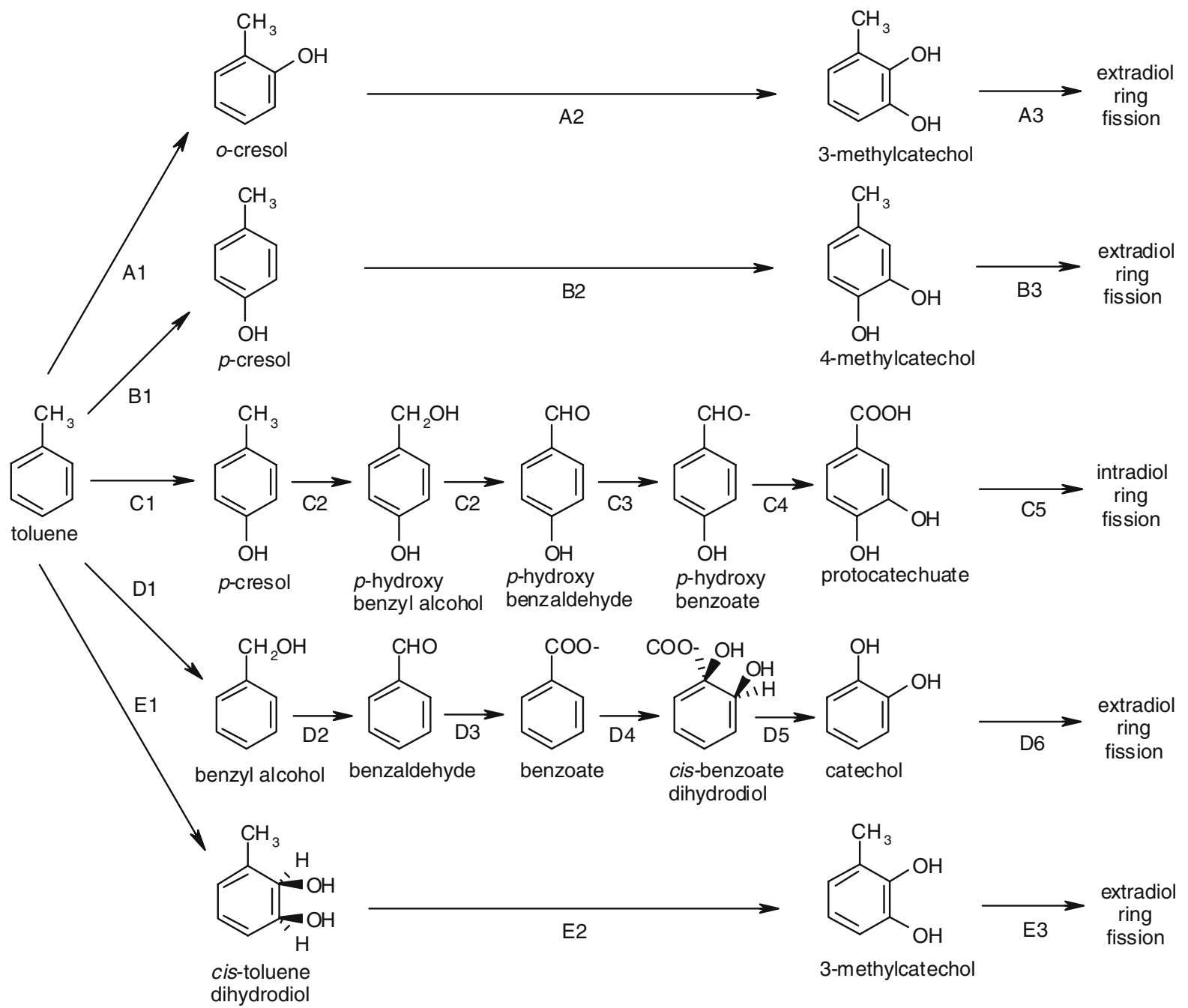

Figure 1. Toluene oxygenase-mediated pathways for the aerobic biotransformation of toluene. Toluene-2-monooxygenase pathway (Pathway A): (A1) toluene-2-monooxygenase, (A2) o-cresol hydroxylase, and (A3) 3-methylcatechol-2,3-dioxygenase. Toluene-4monooxygenase pathway followed by ring cleavage of 4-methyl catechol (Pathway B): (B1) toluene-4-monooxygenase, (B2) p-cresol hydroxylase, and (B3) 4-methylcatechol-3,4-dioxygenase. Toluene-4-monooxygenasae pathway followed by ring cleavage of protocatechuate (Pathway C): (C1) toluene-4-monooxygenase, (C2) p-cresol methylhydroxylase, (C3) p-hydroxybenzaldehyde dehydrogenase, (C4) $p$-hydroxybenzoate hydroxylase, and (C5) protocatechuate-3,4-dioxygenase. Toluene methyl monooxygenase pathway (Pathway D): (D1) methyl monooxygenase, (D2) benzyl alcohol dehydrogenase, (D3) benzaldehyde dehydrogenase, (D4) benzoate1,2-dioxygenase, (D5) dihydroxycyclohexadiene carboxylate dehydrogenase, and (D6) catechol-2,3-oxygenase. Toluene dioxygenase pathway (Pathway E): (E1) toluene-2,3-dioxygenase, (E2) toluene dihydrodiol dehydrogenase, and (E3) 3-methylcatechol-2,3-dioxygenase.

vial containing $0.5 \mathrm{ml}$ of liquid toluene from the culture flask stopper. For similar experimental setups, the resulting aqueous toluene concentration in the culture flask was approximately $230 \mathrm{mg} \mathrm{l}^{-1}$, ensuring enzymatic induction (Leahy \& Olsen 1997).

TCE-induced cells were grown by transferring $1 \mathrm{ml}$ of lactate-grown uninduced cell culture $\left(\mathrm{A}_{425}\right.$ of $0.8-1.0)$ to a $160-\mathrm{ml}$ serum bottle containing $9 \mathrm{ml}$ of preoxygenated BM, $1000 \mathrm{mg}$ sodium DLlactate $1^{-1}$, and either 50,110 , or $150 \mathrm{mg} \mathrm{TCE} 1^{-1}$. The TCE stock was prepared in $N^{\prime} N^{\prime}$-dimethylformamide (900 g TCE per liter of $N^{\prime} N^{\prime}$-dimethylformamide) and added directly to the aqueous phase. The TCE concentration in each serum bottle was reported based upon the initial 


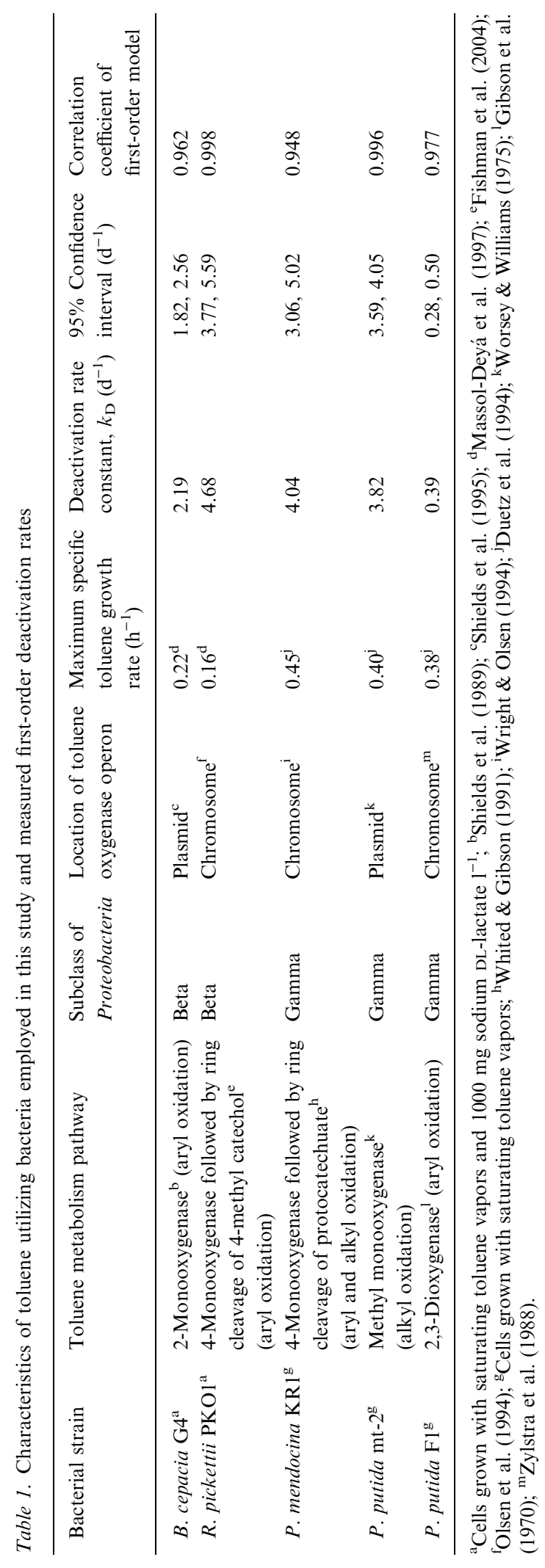

concentration in the aqueous phase. After the addition of TCE, the serum bottles were sealed with Teflon-lined butyl septa, vigorously shaken for $30 \mathrm{~s}$, and incubated for $18 \mathrm{~h}$ at $30^{\circ} \mathrm{C}$.

Starvation cultures were obtained by harvesting toluene- and TCE-induced cells by centrifugation, washing cell pellets with $40 \mathrm{mM}$ phosphate buffer ( $\mathrm{pH}$ 6.7-7.0), and resuspending cells in $200 \mathrm{ml}$ fresh BM to an optical density of 0.1 . Starvation flasks were maintained at room temperature $\left(23-27^{\circ} \mathrm{C}\right)$ with continuous mixing. In the case of the starvation experiment with previously TCE-induced cells, TCE was added at concentrations similar to those used in the previous TCE induction conditions in order to examine the effect of carbon starvation per se in the presence of inducer.

\section{Toluene degradation kinetics}

Rates of toluene degradation were measured in 15-ml bottles. Each bottle was completely filled with culture or with deionized water to serve as a no-cell control for abiotic losses. Bottles were sealed with Teflon-lined butyl septa, amended with liquid toluene to obtain an aqueous concentration of $10 \mathrm{mg}$ toluene $1^{-1}$, and vigorously and continuously mixed. Four aqueous $0.5-\mathrm{ml}$ samples were taken at periodic time intervals after toluene addition using a 1-ml glass syringe. Sampling intervals for specific bacterial strains were as follows: P. putida F1, 2 min; $P$. putida $\mathrm{mt}-2,2$ min; $P$. mendocina KR1, 4 min; B. cepacia G4, 4 min; B. cepacia $\mathrm{G} 4-\mathrm{PR}_{31}, 4 \mathrm{~min}$; $R$. pickettii $\mathrm{PKO} 1$, 15 min. After sample collection, samples were immediately quenched in 1-volume methanol and stored at $4{ }^{\circ} \mathrm{C}$ prior to quantitative analysis. Toluene concentrations for each time point were used to derive linear relationships by regression analysis, providing a quantification of the rate of toluene disappearance. To quantify rate data, the average rate loss of toluene from duplicate abiotic controls was subtracted from the average rate loss of toluene in duplicate biotic experiments. Rates were quantified over the time for disappearance of $30-40 \%$ of the initial mass of toluene from the biotic experiments. Less than $5 \%$ of the total initial mass of toluene was lost in abiotic controls over the same period of time. This also ensured that there would be insignificant effect of toluene partitioning on the measurement of aqueous 
toluene concentrations. Viable biomass-normalized toluene degradation rates were obtained by normalizing toluene degradation rates by the number of colony forming units per reaction volume.

\section{Deactivation rates}

Toluene degradation rates and their corresponding starvation times were used to derive first-order relationships using the following equation:

$$
V\left(t_{\mathrm{cs}}\right)=V_{o} \cdot \exp \left[-k_{\mathrm{D}} \cdot t_{\mathrm{cs}}\right]
$$

where $t_{\mathrm{cs}}$, carbon starvation period; $V\left(t_{\mathrm{cs}}\right)$, specific (biomass-normalized) rate of degradation of toluene as a function of the carbon starvation period $t_{\mathrm{cs}} ; V_{\mathrm{o}}$, specific rate of degradation of toluene by non-starved and induced cells; and $k_{\mathrm{D}}$, first order deactivation rate constant. The deactivation rate, 95\% confidence intervals (CIs), and correlation coefficient were obtained by non-linear regression analysis using the SPSS Regression Models software package (SPSS Inc.). Deactivation rates with overlapping $95 \%$ CIs were considered statistically similar while deactivation rates with nonoverlapping 95\% CIs were considered statistically different.

\section{Toluene culturability assays}

A modification of the toluene plate count method described by Mars and co-workers (1996) was used to quantify the fraction of carbon-starved cells retaining their ability to grow on toluene. Cell suspensions were starved for 4 days, transferred to TNA agar plates, and incubated for 3 days at $30{ }^{\circ} \mathrm{C}$. Colonies were subsequently transferred to solid BM medium and continuously supplied with toluene vapors by adding $5 \mu$ l of liquid toluene to a filter paper disk located in the cover of the plate. The toluene-supplied plates were stored in airtight glass containers for 10 days and the number of resulting colonies was quantified.

\section{Analytical methods}

Toluene was analyzed by reverse-phase high-performance liquid chromatography (HPLC) with a Hewlett-Packard 1090 series II system, a Hypersil $5 \mathrm{C}_{18}$ column, and a UV detection system
(210 nm). The carrier solvent solution was $70 \%$ acetonitrile and $30 \%$ deionized water with a flow rate of $0.35 \mathrm{ml} \mathrm{min}^{-1}$. Detection limits for toluene and TCE were 10 and $1 \mu \mathrm{g}^{-1}$, respectively.

Viable biomass was quantified by a colony plate-count method. Sample cultures were serially diluted and cells were grown on TNA agar plates for 3 days at $30{ }^{\circ} \mathrm{C}$. A single viable cell was assumed to form from one colony (1 CFU). Triplicate dilution series and plate counts were performed for each experimental sample.

\section{Results}

\section{Rapid deactivation in TMO-expressing bacteria}

All the investigated TMO-expressing bacteria deactivate significantly faster than the TDOexpressing bacterium (Table 1). The deactivation rates do not correlate with other biological characteristics, including phylogenetic classification, maximum specific toluene growth rates, and the location of the toluene oxygenase operon (plasmid or chromosome).

\section{Toluene culturability after carbon starvation}

Deactivation may result from the loss of the functional TMO operon, such as by plasmid curing (Duetz \& van Andel 1991; Williams et al. 1988) or by a loss-of-function mutation. The contribution of this type of genetic change towards the observed deactivation responses was assessed by performing a toluene culturability assay. With the exception of $P$. putida mt-2, $100 \%$ of the cells retained their ability to degrade toluene after four days of carbon starvation (Table 2). Even for $P$. putida $\mathrm{mt}-2$, whose toluene oxygenase operon is located on a mobile plasmid (Williams et al. 1988), the number of cells losing their ability to grow on toluene could not account for the observed deactivation behavior.

\section{Effect of previous growth/induction conditions on deactivation}

The effect of previous substrate exposure conditions was examined by growing $B$. cepacia $\mathrm{G} 4$ with either (i) toluene only or (ii) toluene plus lactate. The co-presence of lactate during growth 
Table 2. Toluene culturability assays

\begin{tabular}{lll}
\hline Bacterial strain & $\begin{array}{l}\text { Number of } \\
\text { colonies on } \\
\text { TNA plates } \\
\text { after carbon } \\
\text { starvation }^{\mathrm{a}}\end{array}$ & $\begin{array}{l}\text { Number of } \\
\text { colonies on } \\
\text { toluene-BM } \\
\text { plates after } \\
\text { carbon starvation }^{\mathrm{b}}\end{array}$ \\
\hline R. pickettii PKO1 & 100 & 100 \\
P. mendocina $\mathrm{KR} 1$ & 100 & 100 \\
P. putida mt-2 & 100 & 91 \\
B. cepacia $\mathrm{G} 4$ & 100 & 100 \\
P. putida $\mathrm{F} 1$ & 100 & 100 \\
\hline
\end{tabular}

${ }^{\mathrm{a} A f t e r}$ incubation for 3 days on TNA plates, cells were transferred to toluene-BM plates and incubated for 10 days.

${ }^{\mathrm{b}}$ Cells were starved for 4 days prior to growth on TNA plates.

conditions significantly reduced the initial rate of toluene degradation in non-starved cells (time $=0$ in Figure 2). However, the deactivation rates for the two growth conditions were statistically similar (Table 3), providing evidence that the rate of deactivation is independent of prior substrate exposure conditions.

The effect of previous induction conditions on the rate of deactivation was tested by exposing lactate-grown $R$. pickettii $\mathrm{PKO}$ cells to various concentrations of TCE during both growth and starvation conditions (Table 3). Because TCE induces T4MO activity but is not a metabolic

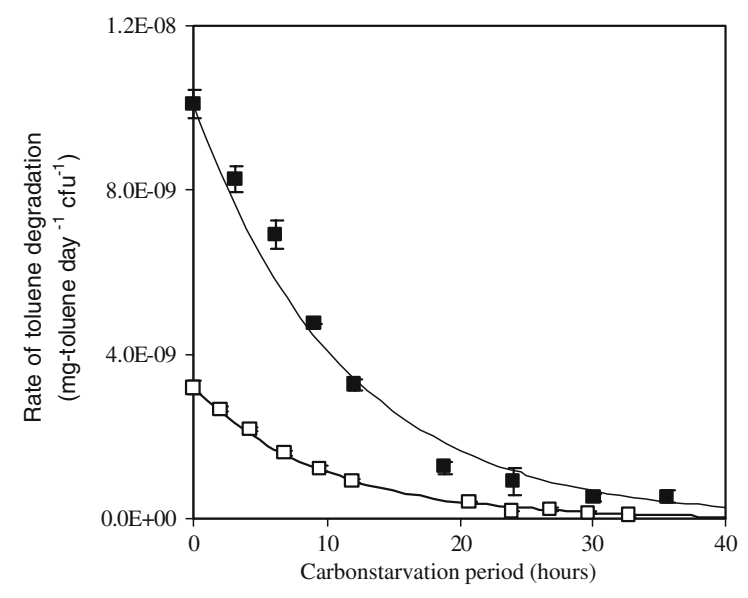

Figure 2. Deactivation of toluene degradation activity in $B$. cepacia G4 cells grown with (Ш) saturating toluene vapors or ( $\square$ ) saturating toluene vapors and $1000 \mathrm{mg}$ sodium DL-lactate $1^{-1}$. Measurements are averages of duplicate experiments and error bars represent one standard deviation. Solid lines are the first-order model predictions obtained by non-linear regression of the experimental data. substrate of the organism (Park et al. 2002), these growth and starvation conditions allowed the effects of carbon starvation and the absence of an inducer to be decoupled. In addition, the selected range of TCE concentrations allowed the effect of TCE toxicity on the deactivation rate to be examined, where the highest concentration of TCE $\left(150 \mathrm{mg}^{-1}\right)$ is toxic to $R$. pickettii $\mathrm{PKO} 1$ and the lower concentrations of TCE (110 and $55 \mathrm{mg}^{-1}$ ) are less toxic (Park et al. 2002). Results show that the deactivation rates for cells exposed to different TCE concentrations are all statistically similar, although the deactivation rate for the toxic concentration of $150 \mathrm{mg} \mathrm{TCE} 1^{-1}$ was smaller than the deactivation rates for the less toxic concentrations of 55 and $110 \mathrm{mg} \mathrm{TCE} 1^{-1}$ (Figure 3, Table 3). These results demonstrate that the rate of deactivation is not significantly affected by the concentration of the inducer. In addition, the deactivation rates for the less toxic concentrations of 55 and $110 \mathrm{mg} \mathrm{TCE} 1^{-1}$ were not significantly different from the deactivation rate for cells previously grown and induced with toluene (Table 3), suggesting that the deactivation rate is independent of the type of inducer (TCE or toluene).

Furthermore, the insignificant differences between deactivation rates for cells starved in the presence (55 and $110 \mathrm{mg} \mathrm{TCE} 1^{-1}$ ) and absence (toluene starvation) of an inducer indicates that

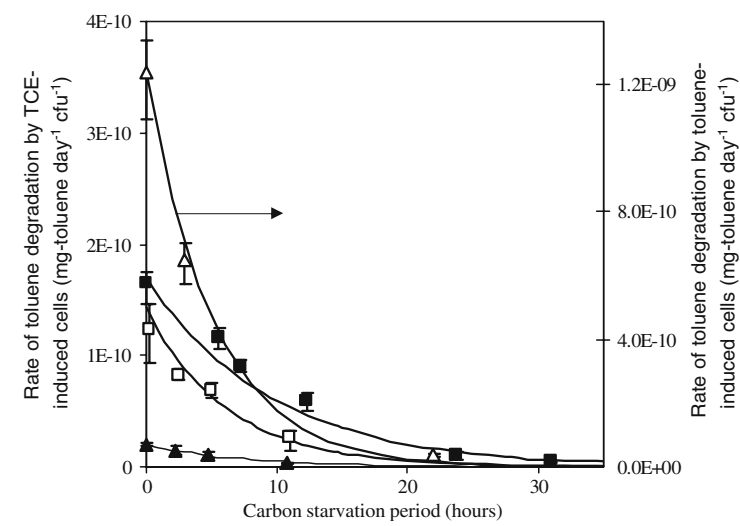

Figure 3. Deactivation of toluene degradation activity in $R$. pickettii $\mathrm{PKO} 1$ cells grown with $1000 \mathrm{mg}$ sodium DL-lacta-

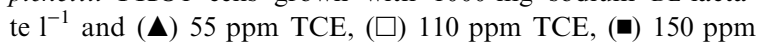
TCE, or $(\Delta)$ saturating toluene vapors. TCE concentrations present during growth conditions were maintained throughout starvation conditions. Measurements are averages of duplicate experiments and error bars represent one standard deviation. Solid lines are the first-order model predictions obtained by non-linear regression of the experimental data. 
Table 3. First-order deactivation rates and growth/induction conditions

\begin{tabular}{|c|c|c|c|c|c|c|}
\hline Bacterial strain & $\begin{array}{l}\text { Type of } \\
\text { regulation }\end{array}$ & Growth conditions $^{\mathrm{a}}$ & $\begin{array}{l}\text { Starvation } \\
\text { conditions }\end{array}$ & $\begin{array}{l}\text { Deactivation } \\
\text { rate constant } \\
k_{\mathrm{D}}\left(\mathrm{d}^{-1}\right)\end{array}$ & $\begin{array}{l}95 \% \text { Confidence } \\
\text { interval }\left(\mathrm{d}^{-1}\right)\end{array}$ & $\begin{array}{l}\text { Correlation } \\
\text { coefficient } \\
\text { of first-order } \\
\text { model }\end{array}$ \\
\hline \multirow[t]{2}{*}{ B. cepacia $\mathrm{G} 4$} & \multirow[t]{2}{*}{ Inducible $^{\mathrm{b}}$} & Toluene & & 2.46 & $2.22,2.70$ & 0.962 \\
\hline & & Toluene + Lactate & & 2.19 & $1.82,2.56$ & 0.993 \\
\hline B. cepacia $\mathrm{G} 4-\mathrm{PR} 131$ & Constitutive $^{c}$ & Toluene + Lactate & & 1.48 & $1.03,1.93$ & 0.979 \\
\hline \multirow[t]{4}{*}{ R. pickettii $\mathrm{PKO} 1$} & \multirow[t]{4}{*}{ Inducible $^{\mathrm{d}}$} & Toluene + Lactate & & 4.68 & $3.77,5.59$ & 0.998 \\
\hline & & $150 \mathrm{mg}$ TCE $1^{-1}+$ Lactate & $55 \mathrm{mg} \mathrm{TCE} 1^{-1}$ & 3.53 & $2.49,4.57$ & 0.992 \\
\hline & & $110 \mathrm{mg}$ TCE $1^{-1}+$ Lactate & $110 \mathrm{mg} \mathrm{TCE} \mathrm{l}^{-1}$ & 3.91 & $2.40,5.42$ & 0.969 \\
\hline & & $55 \mathrm{mg}$ TCE $1^{-1}+$ Lactate & $150 \mathrm{mg} \mathrm{TCE} 1^{-1}$ & 2.51 & $1.93,3.09$ & 0.986 \\
\hline
\end{tabular}

${ }^{a}$ Lactate was supplied at a concentration of $1000 \mathrm{mg}$ sodium DL-lactate $\mathrm{l}^{-1}$, toluene was supplied with saturating toluene vapors;

${ }^{\text {b }}$ Shields et al. (1989); ${ }^{\mathrm{c}}$ Shields \& Reagin (1992); ${ }^{\mathrm{d}}$ Olsen et al. (1994).

deactivation results from carbon starvation and not from the absence of a TMO inducer. This was further supported by comparing deactivations for the induction-dependent $B$. cepacia $\mathrm{G} 4$ and it's constitutively expressing mutant $B$. cepacia G4$\mathrm{PR} 1_{31}$. A significant deactivation was also observed for the constitutively expressing variant although the rate of deactivation was lower than that for the induction-dependent G4 strain.

\section{Discussion}

The deactivation rates for all the investigated TMO-expressing bacteria $\left(2.19-4.68 \mathrm{~d}^{-1}\right)$ were significantly larger than the measured and previously reported deactivation rates for TDOexpressing bacteria $\left(0.39 \mathrm{~d}^{-1}\right.$ [this study]; $0.36 \mathrm{~d}^{-1}$ [Costura \& Alvarez 2000]; $0.30 \mathrm{~d}^{-1}$ [Jenkins \& Heald 1996]). Although minor differences in experimental design between this study and the referenced studies exist, the deactivation rates for $P$. putida $\mathrm{F} 1$ measured in this study and by Costura \& Alvarez (2000) were similar, validating the previous comparison. The deactivation rates for the TMO-expressing bacteria reported here were also significantly larger than those reported for other monooxygenase-expressing bacteria $\left(0.21 \mathrm{~d}^{-1}\right.$ for AMO [Jones \& Morita 1985]; less than $0.2 \mathrm{~d}^{-1}$ for MMO [Roslev \& King 1994]). Together, these observations provide substantial evidence supporting the hypothesis that rapid deactivation is a general characteristic of TMOexpressing bacteria. Further support for this observation is provided by the lack of a correlation between deactivation rates and other organismspecific characteristics, including phylogenetic classification, maximum toluene growth rates, the location of the toluene oxygenase operon (chromosome or plasmid), or the type of regulation of the oxygenase operon (constitutive or inducible).

An analysis of the biochemistry of toluene oxygenase pathways can provide insight into the potential mechanisms controlling the deactivation of in vivo toluene oxygenase activity. TMO pathways require a net consumption of NADH for the toluene biotransformation steps preceding ring cleavage (Wackett \& Hershberger 2001). Based upon these observations, it is reasonable to hypothesize that the fast deactivation of TMOexpressing bacteria may be related to its higher demand for NADH. This hypothesis implies that the NADH demand for the initial catabolic step is greater than the NADH demand for cellular maintenance and respiration. Further investigations that quantify NADH levels as a function of starvation time would be needed to explore the validity of this hypothesis.

An additional and important finding of this study is that the rate of deactivation in TMOexpressing bacteria is independent of previous substrate/inducer exposure conditions, including the co-presence of a more readily degradable substrate and the type, concentration, and existence of an inducer during starvation conditions. In another study with $P$. putida F1, Costura \& Alvarez (2000) demonstrated that the deactivation rate was independent of previous respiration 
conditions (e.g. oxygen concentration). Taken together with the findings reported here, this general independence of deactivation rates on previous culture conditions suggests that the extent of deactivation for a particular organism depends only on the length of the carbon starvation period.

The results presented here have the potential to significantly improve bioremediation design and prediction methodologies. Biostimulation processes involving the addition of a primary growth substrate commonly utilize pulse injections to improve mixing and spatial distribution (McCarty et al. 1998). The addition of pulse injections, however, can result in a condition where organisms experience highly fluctuating substrate concentrations and possible periods of carbon and energy limitations (Lang et al. 1997; McCarty et al. 1998; Park et al. 2001). Accounting for starvation effects, therefore, would be useful for designing the length of the substrate pulse such that deactivation of biodegradation activity is minimized. Additionally, accounting for the effects of carbon starvation would improve the accuracy of quantitative models describing biodegradation in complex natural systems. These models would, in turn, provide more accurate predictions of bioremediation rates and capacity.

\section{Acknowledgements}

We are grateful to Malcolm S. Shields, University of South Florida, for providing Burkholderia cepacia strains $\mathrm{G} 4$ and $\mathrm{G} 4-\mathrm{PR} 1_{31}$, and to Fredrick D. Bost, Rutgers University, for useful discussion. This research was supported by the National Institute of Environmental Health Sciences Superfund Basic Research Program (Grant P42-ES-04911). The content of this report does not necessarily represent the views of the agency.

\section{References}

Alvarez-Cohen L \& McCarty PL (1991) Effects of toxicity, aeration, and reductant supply on trichloroethylene transformation by a mixed methanotrophic culture. Appl. Environ. Microbiol. 57: 228-235

Arciero D, Vannelli T, Logan M \& Hooper AB (1989) Degradation of trichloroethylene by the ammonia-oxidizing bacterium Nitrosomonas europea. Biochem. Biophys. Res. Commun. 159: 640-643

Costura RK \& Alvarez PJJ (2000) Expression and longevity of toluene dioxygenase in Pseudomonas putida F1 induced at different dissolved oxygen concentrations. Water Res. 34: 3014-3018

Duetz WA, De Jong C, Williams PA \& Van Andel JG (1994) Competition in chemostat culture between Pseudomonas strains that use different pathways for the degradation of toluene. Appl. Environ. Microbiol. 60: 2858-2863

Duetz WA \& van Andel JG (1991) Stability of TOL plasmid pWWO in Pseudomonas putida mt-2 under non-selective conditions in continuous culture. J. Gen. Microbiol. 137: 1369-1374

Ensign SA, Hyman MR \& Arp DJ (1992) Cometabolic degradation of chlorinated alkenes by alkene monooxygenase in a propylene-grown Xanthobacter strain. Appl. Environ. Microbiol. 58: 3038-3046

Fishman AF, Tao Y \& Wood TK (2004) Toluene 3-monooxygenase of Ralstonia pickettii $\mathrm{PKO} 1$ is a para-hydroxylating enzyme. J. Bacteriol. 186: 3117-3123

Folsom BR, Chapman PJ \& Pritchard PH (1990) Phenol and trichloroethylene degradation by Pseudomonas cepacia G4: kinetics and interactions between substrates. Appl. Environ. Microbiol. 56: 1279-1285

Fox BG, Borneman JG, Wackett LP \& Lipscomb JD (1990) Haloalkene oxidation by the soluble methane monooxygenase from Methylosinus trichosporium OB3b: mechanistic and environmental implications. Biochemistry 29: 6419-6427

Ghiorse WC \& Wilson JJ (1988) Microbial ecology of the terrestrial subsurface. Adv. Appl. Microbiol. 33: 107-172

Gibson DT, Hensley M, Yoshioka H \& Mabry TJ (1970) Formation of (+)-cis-2,3-dihydroxy-1-methylcyclohexa-4,6diene from toluene by Pseudomonas putida. Biochemistry 7: 2653-2662

Heald S \& Jenkins RO (1994) Trichloroethylene removal and oxidation toxicity mediated by toluene dioxygenase of Pseudomonas putida. Appl. Environ. Microbiol. 60: 4634 4637

Henry SM \& Grbic-Galic D (1991) Influence of endogenous and exogenous electron donors and trichloroethylene oxidation toxicity on trichloroethylene oxidation by methanotrophic cultures from a groundwater aquifer. Appl. Environ. Microbiol. 57: 236-244

Hopkins GD \& McCarty PL (1995) Field evaluation of in situ aerobic cometabolism of trichloroethylene and three dichloroethylene isomers using phenol and toluene as the primary substrates. Environ. Sci. Technol. 29: 1628-1637

Jenkins RO \& Heald SC (1996) Stability of toluene oxidation by Pseudomonas putida under nutrient deprivation. Appl. Microbiol. Biotechnol. 46: 388-392

Jones RD \& Morita RY (1985) Survival of a marine ammonia oxidizer under energy-source deprivation. Mar. Ecol. Prog. Ser. 26: 175-179

Lang M, Roberts PV \& Semprini L (1997) Model simulations in support of field scale design and operation of bioremediation based on cometabolic degradation. Ground Water 35: 565-573

Leahy JG, Byrne AM \& Olsen RH (1996) Comparison of factors influencing trichloroethylene degradation by tolueneoxidizing bacteria. Appl. Environ. Microbiol. 62: 825-833 
Leahy JG \& Olsen RH (1997) Kinetics of toluene degradation by toluene-oxidizing bacteria as a function of oxygen concentration, and the effect of nitrate. FEMS Microbiol. Ecol. 23: 23-30

Lontoh S \& Semrau JD (1998) Methane and trichloroethylene degradation by Methylosinus trichosporium OB3b expressing particulate methane monooxygenase. Appl. Environ. Microbiol. 64: 1106-1114

Malachowsky KJ, Phelps TJ, Teboli AB, Minnikin DE \& White DC (1994) Aerobic mineralization of trichloroethylene, vinyl chloride, and aromatic compounds by Rhodococcus species. Appl. Environ. Microbiol. 60: 542-548

Mars AE, Houwing J, Dolfing J \& Janssen DB (1996) Degradation of toluene and trichloroethylene by Burkholderia cepacia G4 in growth-limited fed-batch culture. Appl. Environ. Microbiol. 62: 886-891

Massol-Deyá A, Weller R, Rios-Hernandez L, Zhou JZ, Hickey RF \& Tiedje JM (1997) Succession and convergence of biofilm communities in fixed film reactors treating aromatic hydrocarbons in groundwater. Appl. Environ. Microbiol. 63: 270-276

McCarty PL, Goltz MN, Hopkins GD, Dolan ME, Allan JP, Kawakami BT \& Carrothers TJ (1998) Full-scale evaluation of in situ cometabolic degradation of TCE in groundwater through toluene injection. Environ. Sci. Technol. 32: 88-100

Morita RY (1993) Bioavailability of energy and the starvation state. In: Kjelleberg S (Ed) Starvation in Bacteria, (pp 18331847). Plenum Press, New York/London

Olsen RH \& Hansen J (1976) Evolution and utility of a Pseudomonas aeruginosa drug resistance factor. J. Bacteriol. 125: 837-844

Olsen RH, Kukor JJ \& Kaphammer B (1994) A novel toluene3-monooxygenase pathway cloned from Pseudomonas pickettii PKO1. J. Bacteriol. 176: 3749-3756

Park J (2001) Influence of Substrate Exposure History on Biodegradation in Porous Media by Ralstonia pickettii PKO1. Doctoral dissertation. The University of Michigan, Ann Arbor, MI

Park J, Kukor JJ \& Abriola LM (2002) TCE concentration dependence of TCE inducibility, cometabolism and toxicity in Ralstonia pickettii PKO1. Appl. Environ. Microbiol. 68: 5231-5240

Park J, Chen Y-M, Kukor JJ \& Abriola LM (2001) Influence of substrate exposure history on biodegradation in a porous medium. J. Contam. Hydrol. 51: 233-256
Roslev P \& King GM (1994) Survival and recovery of methanotrophic bacteria starved under oxic and anoxic conditions. Appl. Environ. Microbiol. 60: 2602-2608

Shields MS, Montgomery SO, Chapman PJ, Cuskey SM \& Pritchard PH (1989) Novel pathway of toluene catabolism in the trichloroethylene-degrading bacterium G4. Appl. Environ. Microbiol. 55: 1624-1629

Shields MS \& Reagin MJ (1992) Selection of a Pseudomonas cepacia strain constitutive for the degradation of trichloroethylene. Appl. Environ. Microbiol. 58: 3977-3983

Shields MS, Reagin MJ, Gerger RR, Campbell R \& Somerville C (1995) TOM, a new aromatic degradative plasmid from Burkholderia (Pseudomonas) cepacia G4. Appl. Environ. Microbiol. 61: 1352-1356

Vroblesky DA \& Champelle FH (1994) Temporal and spatial changes of terminal electron-accepting processes in a petroleum hydrocarbon-contaminated aquifer and the significance for contaminant biodegradation. Water Resour. Res. 30: $1564-1570$

Wackett LP \& Hershberger CD (2001) Biocatalysis and Biodegradation: Microbial Transformation of Organic Compounds. ASM Press, Washington D.C

Whited GM \& Gibson DT (1991) Toluene-4-monooxygenase, a three-component enzyme system that catalyzes the oxidation of toluene to p-cresol in Pseudomonas mendocina KR1. J. Bacteriol. 173: 3010-3016

Williams PA, Taylor SD \& Gibb LE (1988) Loss of the toluenexylene catabolic genes of TOL plasmid pWWO during growth of Pseudomonas putida on benzoate is due to a selective growth advantage of 'cured' segregants. J. Gen. Microbiol. 134: 2039-2048

Worsey MJ \& Williams PA (1975) Metabolism of toluene and xylenes by Pseudomonas putida (arvilla) mt-2: evidence of a new function of the TOL plasmid. J. Bacteriol. 124: 7-13

Wright A \& Olsen RH (1994) Self-mobilization and organization of the genes encoding the toluene metabolic pathway of Pseudomonas mendocina KR1. Appl. Environ. Microbiol. 60: 235-242

Zylstra GJ, McCombie WR, Gibson DT \& Finette BA (1988) Toluene degradation by Pseudomonas putida F1: genetic organization of the tod operon. Appl. Environ. Microbiol. 54: $1498-1503$

Zylstra GJ, Wackett LP \& Gibson DT (1989) Trichloroethylene degradation by Escherichia coli containing the cloned Pseudomonas putida F1 toluene dioxygenase genes. Appl. Environ. Microbiol. 55: 3162-3166 